\title{
Tree Above-And Below-Ground Biomass Allometries for Carbon Stocks Estimation in Secondary Forest of Congo
}

\author{
Romeo Ekoungoulou, ${ }^{1,}$, Xiaodong Liu ${ }^{1}$, Jean Joël Loumeto ${ }^{2}$, Suspense Averti \\ Ifo $^{2,3}$ \\ ${ }^{1}$ Ecology Research Laboratory, College of Forestry, Beijing Forestry University, Beijing 100083, People's \\ Republic of China \\ ${ }^{2}$ Département de Biologie et Physiologie Végétales, Faculté des Sciences et Techniques, Université Marien \\ Ngouabi, BP69 Brazzaville, Republic of Congo \\ ${ }_{3}^{3}$ Département des Sciences Naturelles, Ecole Normale Supérieure, Université Marien Ngouabi, BP 237 \\ Brazzaville, Republic of Congo. \\ "Corresponding author.E-mail: romeoekous@gmail.com
}

\begin{abstract}
In this study, we analyzed the above-ground biomass data for 44 trees with diameter $\geq 10 \mathrm{~cm}$ from Inkou Forest Island in Congo. The aim of this research was to estimate the carbon stocks of above-and belowground biomass in the secondary forest of Lesio-louna (Teke trays in Republic of Congo). The methodology of Allometric equations was used to measure the carbon stock of this natural forest. We were based precisely on the model II which is also called non-destructive method or indirect method of measuring carbon stocks. We used parameters such as the diameter at breast height (DBH) and wood density. The research was done with three circular plots each $1256 \mathrm{~m}^{2}$, with a distance of $100 \mathrm{~m}$ between each plot, depending on the topography of the site of installation of these plots. Thus, the three studied plots with 44 trees recorded were in the secondary forest that is Inkou Forest Island site in Lesio-louna area. The results of this study showed that the average carbon stock in 3 plots of the study was $135.976333 t$ C /ha for above-ground biomass (AGB) and 31.95440763 $t C$ /ha for below-ground biomass (BGB). In this forest ecosystem, the total carbon stock of $A G B$ was more important in this secondary forest compared to the total carbon stock of $B G B$ in this secondary forest with respectively $407.929 \mathrm{t} C$ /ha against $95.8632229 \mathrm{t} C$ /ha. Also, the average carbon stock of Plot 2 was higher for above ground biomass (147.404 t C /ha) compared to Plot1 and Plot3. This study shows that the species density is higher in Plot2 (19 species) compared to the Plot1 (14 species) and Plot2 (11 species). This research indicates that, this tropical forest hold large stores of carbon, yet uncertainty remains regarding their quantitative contribution to global carbon cycle.
\end{abstract}

Keywords: Carbon stock, Secondary forest, aboveground biomass, Inkou Forest Island, Belowground biomass.

\section{Introduction}

Congo basin's countries in general and Republic of Congo in particular, have currently low Greenhouse Gas (GHG) emissions (FAO, 2008). They are also the subject of carbon credit providers for the North and experience the first impacts of climate change (IPCC, 2001 and FAO, 2011). The forest has a very important role in mitigating this phenomenon by photosynthesis (FAO, 2011). Globally, terrestrial ecosystems sequester annually $1.4 \pm 0.7 \mathrm{P}$ g1C.yr ${ }^{-1}$, or $22.2 \%$ about the flux of fossil fuels (IPCC, 2001). The scope of the problem of Climate Change global response is contained in the United Nations Framework Convention on Climate Change adopted at the World Summit on Sustainable Development called "Earth Summit held in Rio de Janeiro, Brazil in 1997 and the Kyoto Protocol adopted at the third session of the conference of the Parties in December 1997 in Kyoto, Japan. Decisions which aimed at stabilizing concentrations of greenhouse gases in the atmosphere at a level which prevents dangerous interference with the global climate system were taken. Since the $13^{\text {th }}$ Conference of the Parties (COP13) to the United Nations Framework Convention on Climate Change (UNFCCC) in Bali in 2007, the UNFCCC has progressively recognized the package of measures now known as REDD+, which stands for Reducing Emissions from Deforestation and forest Degradation, as well as the conservation and sustainable management of forests, and the enhancement of forest carbon stocks in developing country forests. At the COP16 in Cancun in 2010, REDD+ was officially incorporated into the UNFCCC's agreement on climate change. At COP17 in Durban in 2011, negotiators agreed on monitoring guidelines as safeguards for REDD+ implementation and on the means for developing estimates of emissions that would have occurred in the absence of REDD+ (Barnes et al. 1998). Defining legally binding targets for reducing emissions Greenhouse Gas (GHG) emissions for developed countries during the period 2008-2013 was one of the issues (FAO, 2011). This problem which focuses the attention of 
the international community following the combination of two factors, first, the UNFCCC, (2007) report that emissions of Greenhouse Gases (GHG) in the tropics represent between 20 and $25 \%$ of carbon dioxide $\left(\mathrm{CO}_{2}\right)$ therefore retained Rainforest with "living trees" should be considered as a mitigation measure to reduce climate change. Global climate change is a widespread and growing concern that has led to extensive international discussions and negotiations (IPCC, 2001 and Gorte, 2009). Responses to this concern have focused on reducing emissions of greenhouse gases, especially carbon dioxide $\left(\mathrm{CO}_{2}\right)$, and on measuring carbon absorbed by and stored in forests, soils, and water (FAO, 2008). One option for slowing the rise of greenhouse gas (GHG) concentrations in the atmosphere, and thus possible climate change, is to increase the amount of carbon removed by and stored in forests (Gorte, 2009 and FAO, 2011). As Congress debates climate change and options for addressing the issue, ideas for increasing carbon sequestration in forests are likely to be discussed (Gorte, 2009). That is why the countries of the Congo Basin including the Republic of Congo have now grasped the importance of REDD (Reducing Emissions from Deforestation and Degradation) in the post-Kyoto targets and organize for their interests are recognized and taken into account (Chave et al., 2001 and FAO, 2011). Managing standing forests better, and expanding tree cover through socially- and environmentally-responsible reforestation and restoration, are cost- and timeeffective strategies to conserve and enhance carbon stocks and mitigate climate change, as well as to facilitate adaptation. Integrating the + in REDD with carbon conservation in plant systems capitalizes on the potential of whole-of-landscape responses to climate change. Moreover, industrialized countries subject to the obligations of the Kyoto Protocol in reducing their anthropogenic GHG (Greenhouse Gas) purchase AAUs to other countries, or invest in emission reducing projects. They can under certain conditions be given another type of carbon credit (IPCC, 2011). Reference levels (RLs) and reference emission levels (RELs) are most commonly used as a business baselines to assess a country's performance in implementing REDD+ (UNFCCC, 2011). RLs are needed to establish a reference point or benchmark against which actual emissions (and removals) are compared. In fact, emissions reductions cannot be defined without having first agreed on the RL, which is therefore critical for gauging the effectiveness or forest carbon impact of REDD+ policies and activities. New research at CIFOR on a stepwise approach provides guidance on how countries with little data can begin to develop RL, and can improve their estimates as better data becomes available (CIFOR, 2012 and Ekoungoulou et al., 2014). Faced with this situation, the quantification of carbon stocks and fluxes between the various reservoirs continental and aquatic ecosystems are currently a priority to the international community in general and the Intergovernmental Panel on Climate Change in particular. Finally they better predict the potential role of Congolese forest on the evolution of the atmosphere by greenhouse gas emissions and therefore climate change (FAO, 2008). However, these studies have largely focused on the number of trees damaged (Uhl and Vieira, 1989; Uhl et al., 1991; Verissimo et al., 1991; White, 1994). The study of Pinard and Putz, (1996) detailed the carbon impact, but not in the context of gap size or even volume of timber extracted. Thus, in the context of climate change, particular attention is given to carbon a major constituent of greenhouse gas emissions (Chambers et al., 2001 and Chave et al., 2004). The forest has a very important role in mitigating this phenomenon (Hall, 2012). But the assessment of carbon stocks in this ecosystem is not yet known satisfactorily for countries with this heritage can access the "carbon credit" which is another way to take advantage of the forest. Very little information exists in the field of forest carbon on the Congo (FAO, 2011). However, there exist five $(05)$ carbon reservoirs in a forest ecosystem: soil, plant debris (dead wood, dead roots, leaf litter), the air compartment (AGB), belowground biomass (BGB), and herbaceous (Anonymous, 2011 and Ekoungoulou et al., 2014). In Congo, monitoring changes in carbon stocks serves as a method of assessing the impact of forest management activities, and also helps determine the role forest harvesting plays in the global carbon cycle (Brown et al., 2005). To monitor logging impacts on carbon stocks in Republic of Congo, factors are required to link reported data or readily monitored components with the total carbon impact. The two most obvious factors for correlation are volume extracted (which is widely reported) and gap size (which can be determined remotely). Correlation factors can be created through an initial set of ground measurements (Watson et al., 2000). To our knowledge, only one study has created factors linking gap size or volume extracted with biomass damaged (Brown et al., 2000). Many studies have examined logging and associated damage both in conventional and reduced impact scenarios. The use of allometric regression models is a crucial step in estimating above-ground biomass (AGB), yet it is seldom directly tested (Crow, 1978; Cunia, 1987; Brown et al., 1989; Verissimo et al., 1992; Houghton et al., 2001).

Thus, the aim of this study is to estimate the carbon stocks in above-and below-ground biomass in Inkou Forest Island (secondary forest) of Lesiolouna area of Congo. The results of this research 
will be useful to the Congolese program about the carbon forest sequestration by MDDEFREDD+/WRI Project. Within the carbon market, the result of this study (carbon stock in Lesio-louna tropical rainforest) will allow the Republic of Congo to get the carbon credit.

\section{Materials and Methods}

\subsection{Study area}

The study area is located at Lesio-louna $\left(14^{\circ} \mathrm{E}, 4^{\circ} \mathrm{S}\right), 140 \mathrm{~km}$ North East of Brazzaville in Teke Trays (Republic of Congo). Inkou Forest Island is Secondary forest that is in Lesio-louna (Teke Trays from Republic of Congo). So, Lesiolouna is located in the sub-prefecture of Ngabe, the department of Pool in Republic of Congo (Figure 1). Also, Lesio-louna is a wildlife reserve that extends over approximately 173.000 ha (Figure1). Then, the Teke Trays are a wide range of trays starting from Republic of Gabon crossing Republic of Congo to the Democratic Republic of Congo.

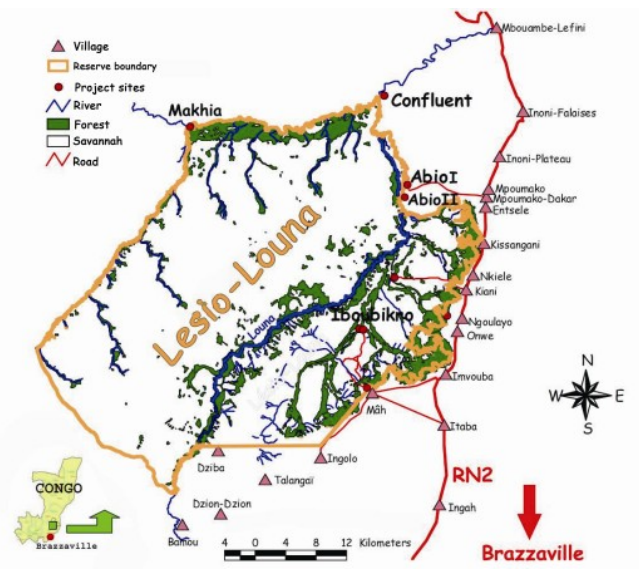

Figure1. Location of study area

(Source: Ekoungoulou et al., 2014)
However, the average annual rainfall is $2100 \mathrm{~mm}$ (2006-2008) with a marked dry season from June to September (Figure 2) and an annual average air temperature of $26^{\circ} \mathrm{C}$ (ANAC, 2010 and Ekoungoulou et al., 2014). The climate of Lesiolouna is a tropical equatorial climate which is characterized by the absence of large dry seasons and low temperature differences (Ekoungoulou et al., 2014). Every month, there shall be at least 50 $\mathrm{mm}$ of water (Figure2). There are two rainy seasons (March-May and September- December) and two dry seasons from June to August and from January to February (Figure 2). In Teke Trays of Lesio-louna, the average annual rainfall is around 1500 to $2000 \mathrm{~mm}$, but the plates is higher and reaches 2000 to $2500 \mathrm{~mm}$. Savannas of Teke trays's South-eastern are wetter than the Southwest, which support only 1400-1800 mm This high rainfall zone extends to Gabon (Nkounkou, 2003). Inter annual variability is important, however, as is common in regions near the equator (FAO, 2008).

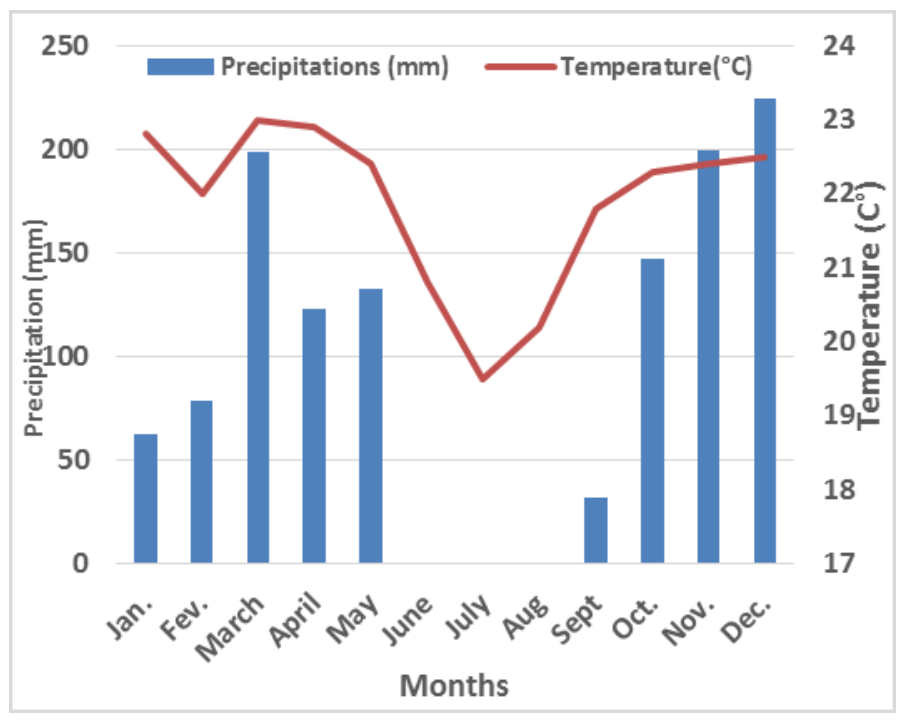

Figure2. Climograph of the main meteorological

station around the study area.

equations of biomass of the highest range and accuracy can be generated using only the diameter at breast height (DBH). During the measurements of this study, the height of the chest was $1.30 \mathrm{~m}$ above the ground for each tree (Cai et al., 2013).

This work was done with the use of the compass to know the North, South, East and West positions. Thus, measurements were made from the center of the plot to the North part, then from the center of the plot to the South part. Following was from the center of plot to the East part, followed from the center of plot to the West part (Figure 3). This work was repeated in all three plots of our study area (Inkou Forest Island) in Lesio-louna 
forest. Also, we used the GPS to meet the GPS waypoint of each plot, about a precision of the geographical position of each plot and the entire study area. So, GPS waypoints were observed in the center of each plot and the compass was used as the center of each plot of this tropical forest.

However, when trees are labeled, the label and the aluminum nail must be placed $10 \mathrm{~cm}$ below the line of diameter at breast height $(\mathrm{DBH})$ to avoid errors arising from bumps and other imperfections that may be found in the same place where the nail penetrates the tree. For future inventories of the measurement will be made by measuring $10 \mathrm{~cm}$ of DBH above the nail. Aluminum nail should be planted deep enough to securely retain the label while leaving enough space to allow the tree to grow. If the objective is that the trees of the project area will be harvested later, the nail and the label must be placed at the base of the tree to avoid any accident involving chain saws and other equipment accidents. Each plot should contain a description of the method used for the next measurement to be carried out with efficiency and accuracy.

Thus, the description of the approach used to measure trees of this study was incorporated into the data collection to allow measurements to be made with precision. The steps to follow were:

- Accurately locate the center of the plot (the use of GPS was used the method);

- As it was circular permanent plots had marks at the center and allocate a unique number to the plot. Experience has shown that the metal rods and PVC pipe work well for marking permanent plots;

- Starting with the North plot, measure DBH trees. Make a mark on the first shaft to indicate the start / end. Measure the chest height $(1.3 \mathrm{~m})$;

- After each tree, move in the clockwise direction to the next tree. If the plots should be measured again later, mark each tree using a numbered label and aluminum nail. It was necessary for us to save the tree species (scientific name). Each tree had a label with number and a scientific name well recorded;

- To allow an accurate count of regrowth (tree grows in the class of the smallest plot size), you must record the location of new trees each census over each nests plot;

- Occasionally trees are near the boundaries of the plots. Typically, plots are small (diameter is $40 \mathrm{~m}$ ) and will be extrapolated to estimate the carbon in biomass per hectare. It is therefore important to carefully decide if a tree is in or out of the plot. If more than $50 \%$ of the shaft is inside the edges of the plot, the shaft is included. If more than $50 \%$ is outside the limits, the shaft is not excluded and is to be measured. It is exactly on the edge of the plot, choose whether inside or outside (Pearson et al. 2005).

Measuring of DBH of tree is important that the diameter at breast height's tape is properly used to ensure the consistency of measurements made. The following steps are to be respected:

- Make sure you have a bar or a pole with a length of $1.3 \mathrm{~m}$ (Brown et al., 1997 and Pearson et al., 2005) to accurately measure line chest height on the tree. If there is none, using a large piece $(2 \mathrm{~cm}$ of diameter) in better. In turn, each member of the survey team should measure itself on the location of the breast height is $1.3 \mathrm{~m}$ above the ground and rely on this site to determine where to put the meter tape;

- DBH tapes have a hook at the end. Push the hook into the bark of the tree and pull the tape to the right. DBH tape is always from the left and be pulled around the tree, even if the operator who takes action is a southpaw;

- When the tape is worn around the shaft and returns to the hook, the tape should be located above the hook. The tape should be upright and not upside down, the numbers must be in the correct reading order;

- If the tree is on a slope, always measure up the slope;

- If the shaft is tilted, the DBH tape should be worn according to the natural angle of the shaft, without taking into account the slope of the ground relative to the horizontal;

- If the tree has a fork at the chest level, take such action under the fork, and if that is not possible, consider that you are measuring two trees;

- If the tree is lying but still alive, then place the measuring stick down and measure at breast height as if the tree was standing. Trees are considered alive if they have green leaves;

- If a vine is growing on a tree to be measured, we do not cut the vine to clear a space to measure the diameter at breast height. If possible, move away from the vine trunk and drag the tape below. If the vine is too large to be removed from the trunk, we use the back of the ribbon and pull the front of the tree to assess the diameter of first hand. Cutting a vine should be the last option because in the long term with repeated measures taken, 
interfere with the natural dynamics of the plot eventually differentiate it from the

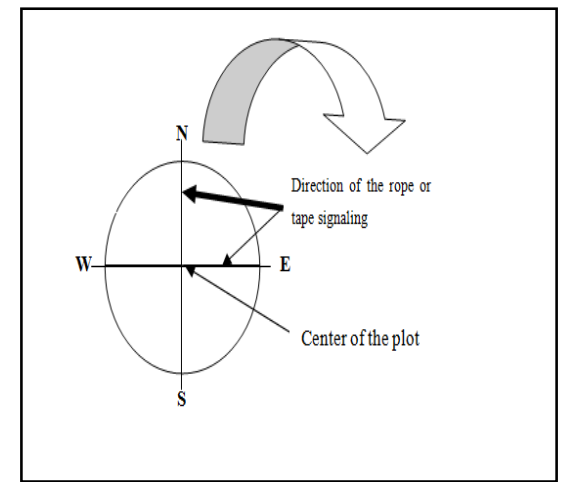

Figure3. Sample plot for trees biomass measurements

\subsection{Data processing and analyzes}

We used the model II of non-destructive method of Chave et al., (2005), to measure the carbon stocks of aboveground biomass in Inkou Forest Island. Chave's equation is a mathematic equation (Chave et al., 2005) to estimate the carbon stock of above ground-biomass. Mokany's equation is a mathematic equation (Mokany et al. (2006) to estimate the carbon stock of belowground biomass. To calculate the carbon stock by using allometric equation of Chave et al., (2005), we used two parameters, which are the wood density and diameter at breast height (DBH). Except allometric equations, the following software was used for statistical data processing: SigmaPlot 10.0; SPSS 18.0 and Microsoft Excel 10 as mentioned by Richard et al., (2007). ArcGIS 10.0 software was used for geographical data processing. The study was made on 44 species, with 3 plots of this forest ecosystem. The circle area of each plot is $1256 \mathrm{~m}^{2}$ (Table $1 \& 3$ ). Then, the total above ground biomass of each tree in every plot was estimated using the following allometric equation:

$$
\begin{gathered}
A G B=\rho^{*} \operatorname{expo}(-1.239+1.980 \ln (D B H)+ \\
\left.0.207(\ln (D B H))^{2}-0.0281(\ln (D B H))^{3}\right)
\end{gathered}
$$

For unidentified species, we applied the mean wood density for each plot weighted, by the number of trees from each species (Ekoungoulou et al., 2014).

The general equation for the rainforests was chosen (Chave et al., 2005): surrounding forest. The same principle has to be respected for any other natural

- species found on a tree.

$$
\begin{gathered}
A G B(\mathrm{~kg})=\rho^{*} \exp (-1.239+1.980 \ln (D)+ \\
\left.0.207(\ln (D))^{2}-0.0281(\ln (D))^{3}\right)
\end{gathered}
$$

For example, one of our study's trees from the plot1 in Inkou Forest Island (secondary forest) had a DBH of $40.3 \mathrm{~cm}$ (Table 1). The scientific name of this tree is Musanga cecropioides (Urticaceae).Then, $40.3 \mathrm{~cm}$ is well within the maximum diameter at breast height for this equation, which is reliable up to $148 \mathrm{~cm}$.

$$
\begin{gathered}
A G B(\mathrm{~kg})=\rho^{*} \exp (-1.239+1.980 \ln (D)+ \\
\left.0.207(\ln (D))^{2}-0.0281(\ln (D))^{3}\right) \\
\rho=0.05 g \mathrm{~cm}^{-3} \\
D=D B H=40.3 \mathrm{~cm} \\
A G B(\mathrm{~kg})=\rho^{*} \exp (-1.239+1.980 \ln (D B H)+ \\
\left.0.207(\ln (D B H))^{2}-0.0281(\ln (D B H))^{3}\right)
\end{gathered}
$$

The biomass of this Musanga cecropioides is 211.5 $\mathrm{kg}$, so $0.2115 \mathrm{t}$. Then, to determine the carbon quantity of this tree (Musanga cecropioides), we divided the biomass obtained by two (Chave et al., 2005 and Duque et al., 2012). So, the carbon stock estimation of this Musanga cecropioides from plot 1 is $0.1057 \mathrm{t} \mathrm{C}$.

To estimate the carbon stock of the below-ground biomass (BGBC), we used the equation from Mokany et al. (2006). The equation from Mokany et al. (2006) is as follows:

$Y=0.235^{*} A G B$ if $A G B C>62.5 t C / h a$ (1)

$Y=0.205^{*} A G B$ if $A G B C \leq 62.5 t C / h a$

So, $Y=B G B C=$ Below-ground biomass carbon ( $\mathrm{t} \mathrm{C}$ /ha)

(1) $B G B C=0.235^{*} A G B$ if $A G B C>62.5 t$ $C / h a$

(2) $B G B C=0.205 * A G B$ if $A G B C \leq 62.5 t$ $C / h a$ 
IOSR Journal of Environmental Science, Toxicology and Food Technology (IOSR-JESTFT) e-ISSN: 2319-2402,p- ISSN: 2319-2399.Volume 8, Issue 4 Ver. II (Apr. 2014), PP 09-20 www.iosrjournals.org

Table1. Distribution of carbon stocks and area state in Inkou Forest Island (Secondary forest)

\begin{tabular}{|c|c|c|c|c|c|c|c|c|}
\hline Plot & $\begin{array}{l}\text { Forest } \\
\text { Type }\end{array}$ & $\begin{array}{c}\text { Nb. } \\
\text { Trees }\end{array}$ & $\mathbf{A G B}^{\mathrm{b}}$ & $\mathbf{B G B}^{\mathrm{c}}$ & Nest Area $^{d}$ & Site & $\begin{array}{c}\text { Average } \\
\text { DBH }^{\mathrm{a}}\end{array}$ & Area State \\
\hline P1 & $\begin{array}{c}\text { Secondary } \\
\text { forest }\end{array}$ & 14 & 137.914 & 32.4098172 & 1256 & $\begin{array}{l}\text { Inkou } \\
\text { forest } \\
\text { island }\end{array}$ & 30.75 & Normal \\
\hline P2 & $\begin{array}{l}\text { Secondary } \\
\text { forest }\end{array}$ & 19 & 147.404 & 34.639853 & 1256 & $\begin{array}{l}\text { Inkou } \\
\text { forest } \\
\text { island }\end{array}$ & 30.9894737 & Normal \\
\hline P3 & $\begin{array}{l}\text { Secondary } \\
\text { forest }\end{array}$ & 11 & 122.611 & 28.8135527 & 1256 & $\begin{array}{l}\text { Inkou } \\
\text { forest } \\
\text { island }\end{array}$ & 42.0181818 & $\begin{array}{c}\text { ecosystem } \\
\text { disturbance } \\
\text { by fire }\end{array}$ \\
\hline
\end{tabular}

${ }^{a}:$ diameter at breast height $(\mathrm{cm}) ;{ }^{b}$ : carbon stock of above-ground biomass $(\mathrm{t} C / \mathrm{ha}) ;{ }^{c}:$ carbon stock of belowground biomass (t C/ha); p: Plot; ${ }^{d}$ : Nest area $\left(\mathrm{m}^{2}\right)$.

\section{Results and discussion}

This study was realized in one site of Lesio-louna in Congo, which is: Inkou Forest Island. Concerning trees sampling in this Lesiolouna forest, we used the $\mathrm{DBH} \geq 10 \mathrm{~cm}$ because this tropical rainforest is not quite young as suggested by some authors (Folega et al., 2011 and Alvarez et al., 2012). The stems less than $10 \mathrm{~cm}$ would be measured in a forest quite young (FAO, 2008). However, this study was done with 6 circular plots each $1256 \mathrm{~m}^{2}$, so $20 \mathrm{~m}$ of radius by plot (Table 1). In this study, all three plots are in the secondary forest, precisely in Inkou Forest Island. So, there are three plots of secondary forest include 44 trees measured during the study. The total number of trees measured in this study for the study site was 44 trees (Figure 4).

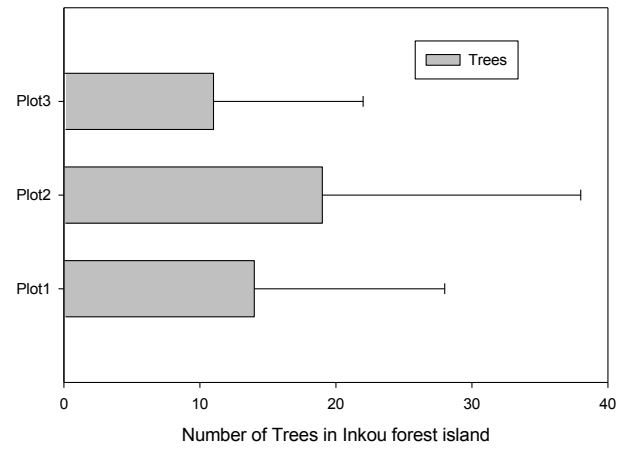

Figure4. Total number of trees recorded in Inkou Forest Island (Secondary forest) by plot.

Table2. Distribution of trees in three plots of Inkou Forest Island by diameter class

\begin{tabular}{ccccc}
\hline Plot & $\mathbf{N T}_{\mathbf{1}}$ & $\mathbf{N T}_{\mathbf{2}}$ & $\mathbf{N T}_{\mathbf{3}}$ & $\mathbf{T T}$ \\
\hline P1 & 8 & 5 & 1 & 14 \\
P2 & 6 & 13 & 0 & 19 \\
P3 & 2 & 6 & 3 & 11 \\
\hline TT & 16 & 24 & 4 & 44
\end{tabular}

TT: Total of trees: $N T_{1}$ : Number of trees with diameter class 10-30 cm of DBH; $N T_{2}:$ Number of trees with diameter class 30-60 cm of DBH; $\mathrm{NT}_{3}$ : Number of trees with diameter class $>60 \mathrm{~cm}$ of DBH; P: Plot. 


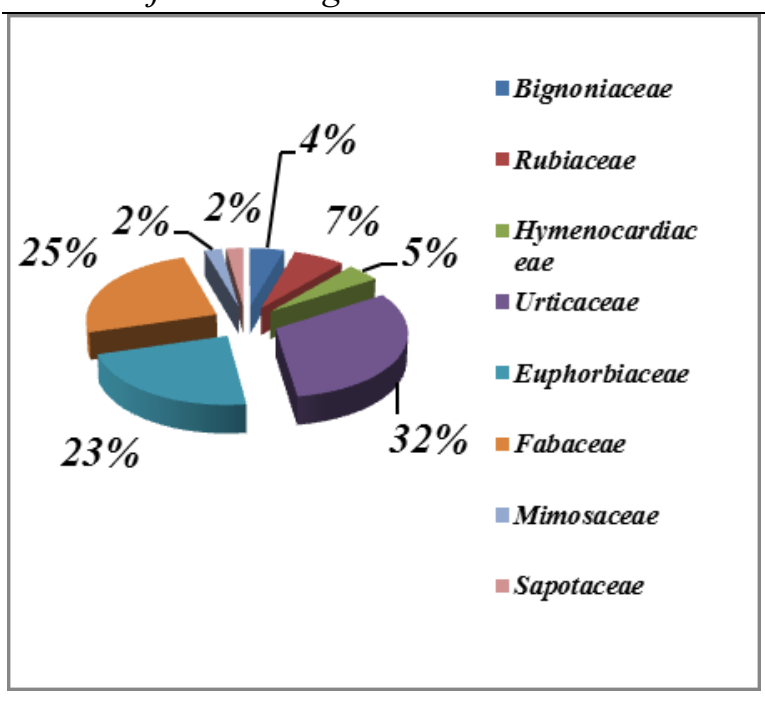

Figure5. Frequency of specific spectra families recorded in Inkou Forest Island

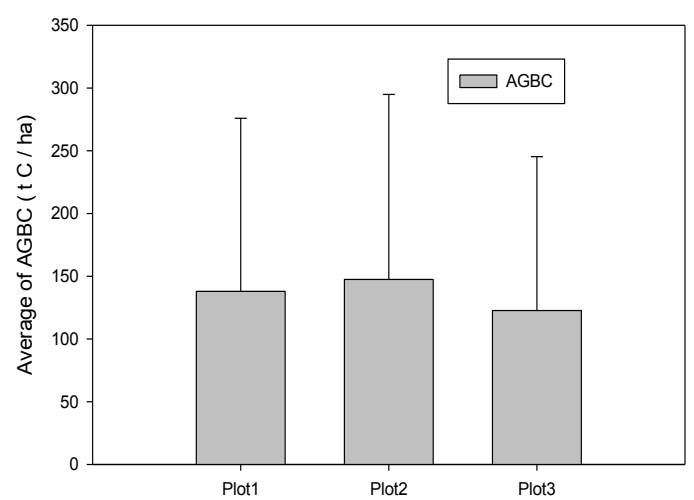

Figure6. Average of above-ground biomass carbon in three plots of study site (Inkou Forest Island)

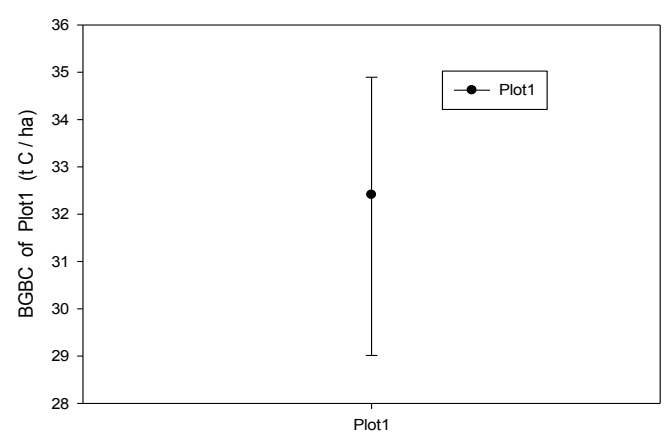

Figure7. Carbon stock (t C /ha) of Belowground biomass about the Plot1 in all three plots of Inkou forest island (study area)

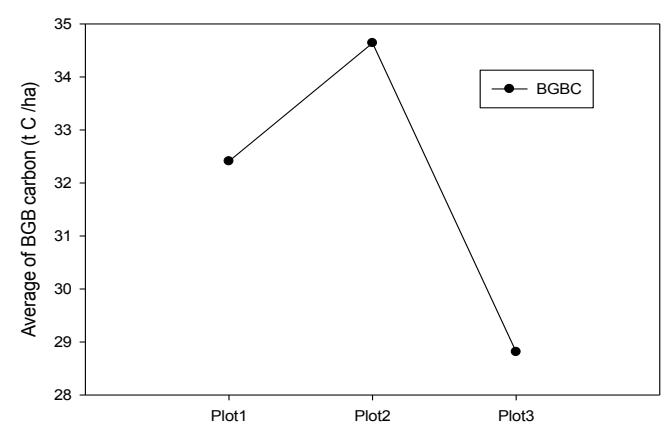

Figure8. Average of carbon stocks (t $\mathrm{C} / \mathrm{ha}$ ) of belowground biomass in Inkou forest island (Secondary forest)

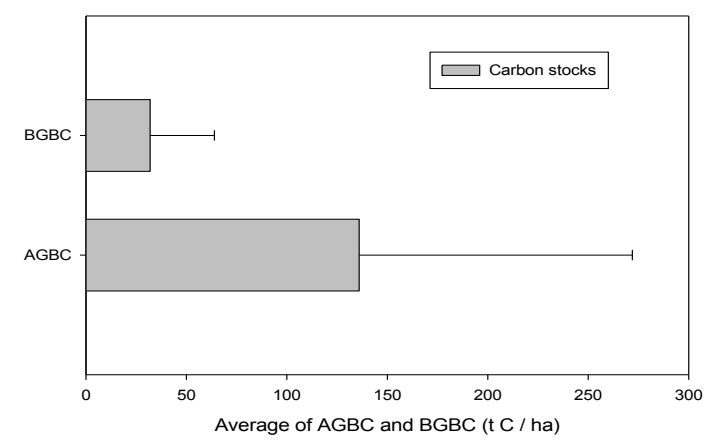

Figure9. Average of carbon stocks (t C /ha) of above-and below-ground biomass in Inkou Forest Island.

The 44 trees in study area are the trees with DBH $\geq 10 \mathrm{~cm}$ (Brown et al., 1989 and Ekoungoulou et al., 2014). For the distribution of trees by diameter class, we observed in the study area: 16 trees for the diameter class $10-30 \mathrm{~cm}, 24$ trees for the diameter class $30-60 \mathrm{~cm}$ and 4 trees for the diameter class $>60 \mathrm{~cm}$. We obtained the high number of trees in the diameter class 30-60 which is precisely in plot 2 with 13 trees (Table2). However, the diameter class $30-60 \mathrm{~cm}$ has a high number of trees (24 trees), followed by diameter class $10-30 \mathrm{~cm}$ (16 trees) and diameter class $>60 \mathrm{~cm}$ with 4 trees (Table 2). In three plots of this forest (Inkou Forest Island), the plot 2 has the highest number of trees (19 trees), followed by plot 1 (14 trees) and plot3 with 11 trees. This secondary forest of Inkou has 44 trees recorded during this study (Table 2).

Thus, this research shows that in this Inkou Forest Island (Secondary forest) there are forty four species distributed in 8 families (Figure 5). The family of Urticaceae (14 species or 32percent of frequency) contains the greatest number of species, followed by the Fabaceae family with eleven species (Table 3) or twenty five percent of 
frequency. The family of Mimosaeace has a frequency of two percent with only one species (Figure 5).

This study shows that, the carbon stock is higher in above-ground biomass with 135.976333 t C / ha compared to below-ground biomass with 31.95440763 t C / ha (Figure 9). The carbon stock was higher in the AGB compared to the BGB in this secondary forest as reported by Gorte (2009). The total carbon in Inkou Forest Island was $407.929 \mathrm{t}$ for above ground biomass (AGB), and $95.8632229 \mathrm{t}$ for below-ground biomass (BGB). We found that in this tropical forest, the total carbon stock (AGBC+BGBC) was $503.7922 \mathrm{t}$ (Table 1).

In this studied tropical forest, about above ground biomass, the plot2 (147.404 t C / ha) has the highest carbon stocks (Figure 6) while the plot 3 contains lesser stocks of carbon (122.611 t C / ha). The Plot 3 is in the area that the ecosystem was disturbance by fire. But the plot 3 is in the area ecosystem without disturbance by fire.

The study from Grote, (2009) about the carbon sequestration in forest, shows that Widespread concern about global climate change has led to interest in reducing emissions of carbon dioxide $\left(\mathrm{CO}_{2}\right)$ and, under certain circumstances, in counting additional carbon absorbed in soils and vegetation as part of the emissions reductions. Congress may consider options to increase the carbon stored (sequestered) in forests as it debates this and related issues. Forests are a significant part of the global carbon cycle. Plants use sunlight to convert $\mathrm{CO}_{2}$, water, and nutrients into sugars and carbohydrates, which accumulate in leaves, twigs, stems, and roots. Plants also respire, releasing $\mathrm{CO}_{2}$. Plants eventually die, releasing their stored carbon to the atmosphere quickly or to the soil where it decomposes slowly and increases soil carbon levels. However, little information exists on the processes and diverse rates of soil carbon change (FAO, 2008).

How to account for changes in forest carbon has been contentious. Land use changes especially afforestation and deforestation can have major impacts on carbon storage. Foresters often cut some vegetation to enhance growth of desired trees. Enhanced growth stores more carbon, but the cut vegetation releases $\mathrm{CO}_{2}$; the net effect depends on many factors, such as prior and subsequent growth rates and the quantity and disposal of cut vegetation. Rising atmospheric $\mathrm{CO}_{2}$ may stimulate tree growth, but limited availability of other nutrients may constrain that growth.

Saatchi et al., 2011 about Benchmark map of forest carbon stocks in tropical regions across three continents determined that The total biomass carbon stock of forests in the study region is estimated to be 247 Gt C, with 193 Gt C stored aboveground and 54 Gt $\mathrm{C}$ stored belowground in roots. Forests in Latin America, sub-Saharan Africa, and Southeast Asia accounted for 49\%, 25\%, and $26 \%$ of the total stock, respectively. By analyzing the errors propagated through the estimation process, uncertainty at the pixel level (100 ha) ranged from $\pm 6 \%$ to $\pm 53 \%$, but was constrained at the typical project (10.000 ha) and national $(>1.000 .000 \mathrm{ha})$ scales at ca. $\pm 5 \%$ and ca. $\pm 1 \%$, respectively. The benchmark map illustrates regional patterns and provides methodologically comparable estimates of carbon stocks for 75 developing countries where previous assessments were either poor or incomplete.

Secondary forests are also called dry forests. These are fragments of forests hooks slopes or hilltops belong to two types of training: some are anthropogenic, others are natural (FAO, 2010). The man-groves are easy to recognize: they are always situated on hilltops more or less flat and consist of typical species of secondary recruits, such as including Alchornea cordifolia, Hurungana madagascariensis and Vernonia conferta. These shrubs or small trees form dense thicket almost impenetrable from which emerge as the largest trees Albizia adianthifolia, Anthocleista schweinfurthii, Millettia laurentii or a significant number of Dracaena sp. Thus, these natural groves are easy to recognize and are located on slopes (Ekoungoulou et al., 2014).

They are often stiff or hollow cash but often without permanent stream. Secondary species listed above, and which form the bulk of anthropogenic groves, develop only in their edge, because, despite the frequent fires, these forests are extended. In this vegetation of Lesio-louna, there are observing the development of the forest gradually in Savannah (Nkounkou, 2003). In Inkou Forest Island and throughout the area of Lesiolouna, the forest advance gradually to savanna beginning with creation of groves and forest island as mentioned by Nkounkou (2003). Natural groves are virtually everywhere expanding, despite the very frequent fires, their edges slowly occupied ground on the savannah (FAO, 2010). Also, there is spontaneous appearance of new groves in the savannah. This process of colonization is common near existing groves, but it can also be born (the grove) at a greater distance. The seeds of pioneer species are transported by birds or frugivorous mammals (IPCC, 2001 and FAO, 2010). Most often, they germinate in the shade of a large Albizia adianthifolia and one of the first plants to begin this succession is Aframomum alboviolaceum, one of the species that make up the Aframomum of Lesio-louna (Nkounkou, 2003).

Once installed, among grass seeds, such as Panicum spp, the Zingiberaceae (Aframomum genus) extends not only by the release of its 
enclosed in a long red fruit, sugar seeds, perfumes and much appreciated by both animals by humans, but also by the formation of long creeping rhizomes progressing just below the soil surface (FAO, 2010) . Gradually she smothers species of the Poaceae. Other woody plants bass are added: an Apocynaceae, which remains undetermined, and Rubiaceae with large rounded leaves (Pseudosabicea stheula) which form dense mats (Nkounkou, 2003).

When this vegetation forms a sufficiently dense mass, fire penetrates more easily under the big tree and other woody announcing the nascent forest can be installed without being destroyed by fire in the next dry season (Ekoungoulou et al., 2014). Thus we see appear Anthocleistra schweinfurthii, recognizable by its huge leaves that can reach more than two meters long, Millettia laurentii (wenge), which forms wide crowns, dense and spreading, Harungana madacascariensis, Caloncoba welwitschii and Alchornea cordifolia, to mention only the most common species .

This vegetation forms in a few years filled with intricate fire can only toast the edge. Only natural fires occurring at intervals of several years and fed by large accumulations of fuel could develop enough heat to penetrate into the interior of these groves and destroy. But these lights then no longer exist. It is therefore likely very frequent fires currently raging ultimately promoting or accelerating forest colonization (Makany, 1976).

However, about our study, the average carbon stock for above-ground biomass (AGB) in this Inkou Forest Island (135.976333 t C / ha) is higher than the carbon stock for BGB $(95.8632229 \mathrm{t} \mathrm{C} \mathrm{/}$ ha). In this study, we found that the carbon stock is in large quantities in the above ground biomass compared to the below ground biomass as reported by Brown et al., 1989; Breugel et al., 2011; Cai, 2013 and Ekoungoulou et., al., 2014. We deduce that the amount or carbon stock for $\mathrm{AGB}+\mathrm{BGB}$ in a study plot is still not affected by the number of species in this plot. Thus, the stock of carbon (AGB + BGB) in a study plot is influenced by biological type of species that constitute this study plot (Table $3)$. The results of this work show that, plots dominated by species of the family of Urticaceae contain a high carbon stock compared to other families studied as mentioned by Breugel et al., (2011)

Table3. Distribution of species recorded in secondary forest (Inkou Forest Island) of Lesio-louna area

\begin{tabular}{clcccc}
\hline $\begin{array}{c}\text { No. } \\
\text { Label }\end{array}$ & Species $^{\text {a }}$ & Families & FT & Plot & DBH \\
\hline $\mathbf{1}$ & Markhamia sessilis & Bignoniaceae & SF & Plot1 & 18.3 \\
$\mathbf{2}$ & Markhamia sessilis & Bignoniaceae & SF & Plot1 & 12.3 \\
$\mathbf{3}$ & Colletoecema dewevrei & Rubiaceae & SF & Plot1 & 15.5 \\
$\mathbf{4}$ & Hymenocardia ulmoides & Hymenocardiaceae & SF & Plot1 & 17 \\
$\mathbf{5}$ & Musanga cecropioides & Urticaceae & SF & Plot1 & 13.1 \\
$\mathbf{6}$ & Macaranga barteri & Euphorbiaceae & SF & Plot1 & 11.8 \\
$\mathbf{7}$ & Millettia laurentii & Fabaceae & SF & Plot1 & 49.4 \\
$\mathbf{8}$ & Musanga cecropioides & Urticaceae & SF & Plot1 & 40.3 \\
$\mathbf{9}$ & Macaranga barteri & Euphorbiaceae & SF & Plot1 & 23.1 \\
$\mathbf{1 0}$ & Macaranga barteri & Euphorbiaceae & SF & Plot1 & 21.4 \\
$\mathbf{1 1}$ & Macaranga barteri & Euphorbiaceae & SF & Plot1 & 31.4 \\
$\mathbf{1 2}$ & Macaranga barteri & Euphorbiaceae & SF & Plot1 & 45.1 \\
$\mathbf{1 3}$ & Millettia laurentii & Fabaceae & SF & Plot1 & 51.8 \\
$\mathbf{1 4}$ & Millettia laurentii & Fabaceae & SF & Plot1 & 80 \\
$\mathbf{1 5}$ & Oxyanthus speciosus & Rubiaceae & SF & Plot2 & 11.2 \\
$\mathbf{1 6}$ & Macaranga barteri & Euphorbiaceae & SF & Plot2 & 12.2 \\
$\mathbf{1 7}$ & Colletoecema dewevrei & Rubiaceae & SF & Plot2 & 19.5 \\
$\mathbf{1 8}$ & Macaranga barteri & Euphorbiaceae & SF & Plot2 & 31.7 \\
$\mathbf{1 9}$ & Macaranga barteri & Euphorbiaceae & SF & Plot2 & 39.5 \\
$\mathbf{2 0}$ & Macaranga barteri & Euphorbiaceae & SF & Plot2 & 31.2 \\
$\mathbf{2 1}$ & Musanga cecropioides & Urticaceae & SF & Plot2 & 41.4 \\
$\mathbf{2 2}$ & Macaranga barteri & Euphorbiaceae & SF & Plot2 & 21.5 \\
$\mathbf{2 3}$ & Musanga cecropioides & Urticaceae & SF & Plot2 & 41.2 \\
$\mathbf{2 4}$ & Musanga cecropioides & Urticaceae & SF & Plot2 & 31.9 \\
$\mathbf{2 5}$ & Musanga cecropioides & Urticaceae & SF & Plot2 & 39.2 \\
$\mathbf{2 6}$ & Musanga cecropioides & Urticaceae & Plot2 & 35.8 \\
\hline & & & & \\
\hline
\end{tabular}


Tree Above-And Below-Ground Biomass Allometries For Carbon Stocks Estimation In Secondary...

\begin{tabular}{llllll}
\hline $\mathbf{2 7}$ & Musanga cecropioides & Urticaceae & SF & Plot2 & 31.1 \\
$\mathbf{2 8}$ & Musanga cecropioides & Urticaceae & SF & Plot2 & 31.6 \\
$\mathbf{2 9}$ & Musanga cecropioides & Urticaceae & SF & Plot2 & 21.4 \\
$\mathbf{3 0}$ & Musanga cecropioides & Urticaceae & SF & Plot2 & 29.2 \\
$\mathbf{3 1}$ & Musanga cecropioides & Urticaceae & SF & Plot2 & 34.5 \\
$\mathbf{3 2}$ & Musanga cecropioides & Urticaceae & SF & Plot2 & 32.4 \\
$\mathbf{3 3}$ & Musanga cecropioides & Urticaceae & SF & Plot2 & 52.3 \\
$\mathbf{3 4}$ & Millettia laurentii & Fabaceae & SF & Plot3 & 15.5 \\
$\mathbf{3 5}$ & Millettia laurentii & Fabaceae & SF & Plot3 & 36.6 \\
$\mathbf{3 6}$ & Millettia laurentii & Fabaceae & SF & Plot3 & 31.1 \\
$\mathbf{3 7}$ & Millettia laurentii & Fabaceae & SF & Plot3 & 28.7 \\
$\mathbf{3 8}$ & Pentaclethra eetveldeana & Mimosaceae & SF & Plot3 & 32.7 \\
$\mathbf{3 9}$ & Hymenocardia ulmoides & Hymenocardiaceae & SF & Plot3 & 40.4 \\
$\mathbf{4 0}$ & Omphalocarpum elatum & Sapotaceae & SF & Plot3 & 39.1 \\
$\mathbf{4 1}$ & Millettia laurentii & Fabaceae & SF & Plot3 & 38.2 \\
$\mathbf{4 2}$ & Millettia laurentii & Fabaceae & SF & Plot3 & 71.7 \\
$\mathbf{4 3}$ & Millettia laurentii & Fabaceae & SF & Plot3 & 65.5 \\
$\mathbf{4 4}$ & Millettia laurentii & Fabaceae & SF & Plot3 & 62.7 \\
\hline
\end{tabular}

No Label: Number of Label; a: Scientific name of tree; DBH: Diameter at breast height (cm); FT: Forest type; SF: Secondary Forest.

\section{Conclusion}

This study allowed us to estimate the carbon stock of above-ground biomass (AGB) and below-ground biomass (BGB) in Inkou Forest Island (secondary forest of Congo). We used the model II of the allometric equations methodology from Chave et al., (2005) with two main parameters, including wood density and DBH. To estimate the carbon stocks of the below-ground biomass (BGB), we used the equation from Mokany et al. (2006). This study was done with three circular plots each $1256 \mathrm{~m}^{2}$ (20m radius / plot). All the three plots studied were in secondary forest of Inkou. However, with the 3 plots, we made measurements on a total of forty four trees with 16 trees for the class of $10-30 \mathrm{~cm}$ diameter, 24 trees for the class of $30-60 \mathrm{~cm}$ diameter and 4 trees in the diameter class $>60 \mathrm{~cm}$. The results of this study indicate that throughout this forest, the carbon stock for above-ground biomass (AGB) was $135.97633 \mathrm{t} \mathrm{C} / \mathrm{ha}$ and $31.95440763 \mathrm{t} \mathrm{C} /$ ha for below-ground biomass (BGB). Plot 2 was the most dominant in terms of carbon stocks in the study site. In this secondary forest, Millettia laurentii (Fabaceae) of plot 1 in Inkou Forest Island has a higher DBH $(80 \mathrm{~cm})$ among the 44 species in the study area (Table 4). But the plot 1 (Figure 7) in Inkou Forest Island that Millettia laurentii, contains 137.914 ( $\mathrm{t} \mathrm{C} / \mathrm{ha}$ ) of carbon stock for above-ground biomass (AGB) and 32.40981721 t C / ha for below-ground biomass (BGB). For cons, the plot 2 has the most dominant of carbon stock (147.404 t C /ha for AGB) compared to the others studied plots (Figure $6 \& 8$ ). Tablel shows that in this study, the area state of Plot1 and Plot2 are normal (in this area there is no disturbance of the ecosystem by anthropogenic action), but the area state of Plot 3 is an ecosystem disturbance by fire (disturbance of ecosystem by human action).

\section{Acknowledgments}

The authors grateful acknowlege Chinese and Congolese governments by Beijing Forestry University, Université Marien Ngouabi, MDDEFE - REDD+/WRI Project and Lesio-louna Project (Ministry of Sustainable Development, Forest Economy and Environment + The Aspinall Foundation) for supporting this academic research.

\section{References}

[1]. ANAC, Situation Météorologique Nationale, Rapport annuel de l'agence nationale de l'aviation civile. Agence Nationale de 1'Aviation Civile (ANAC), Unpublished, Pp. 47-64, Republic of Congo, 2010.

[2]. ANAC, Situation Météorologique Nationale. Rapport annuel de l'agence nationale de l'aviation civile (ANAC). Ministère de transport et de l'aviation civile (Republic of Congo). Unpublished. Brazzaville, Congo, pp. 59-82, 2013

[3]. Anonymous, Annual report of Lesio-louna Project (Rapport annuel du projet Lesio-louna). Ministry of sustainable development, Forest Economy and Environment (Ministère de Développement Durable, de l'Economie Forestière et de l'Environnement), The Aspinall foundation, pp.36-55, Brazzaville, Congo, 2011

[4]. V. B. Barnes, et al., 'Forest ecology". Fourth edition, pp. 563-774, USA, 1998

[5]. V. M. Breugel et al., Estimating carbon stock in secondary forests: Decisions and uncertainties associated with allometric biomass models, Elsevier, Forest Ecology and Management, pp. 1648-1657, 2011.

[6]. S. Brown, A. Gillespie, and A. E. Lugo, Biomass estimation methods for tropical forest with applications 
to forest inventory data. Forest Science Vol. 35, pp. 881-902, 1989.

[7]. S. Brown, Estimating biomass and biomass change of tropical forests: a primer UN FAO Forestry Paper 134, http://www.fao.org/docrep/W4095E/W4095E00.htm. pp.35-55, 1997.

[8]. S. Brown et al., Application of Multispectral 3Dimensional Aerial Digital Imagery for Estimating Carbon Stocks in a Tropical Pine Savanna. Report to the Nature Conservancy Conservation Partnership Agreement, pp. 11-22, 2004.

[9]. S. Brown et al., "'Impact of selective logging on the carbon stocks of tropical forests": Republic of Congo as a case study. Winrock International. Deliverable 6 to USAID, Cooperative Agreement No. EEM A-00-0300006-00, pp. 10-21, 2005.

[10]. S. Brown, Creating a virtual tropical forest from threedimensional aerial imagery to estimate carbon stocks, Ecological Applications, pp.5-13, 2005.

[11]. K. P. Burnham and D.R. Anderson, Model selection and inference, A practical information-theoretic approach, Second edition, Springer, Berlin, Heidelberg, Germany. 2002.

[12]. S. Cai, X. Kang, L. Zhang, Allometric models for aboveground biomass of ten tree species in northeast China, Ann. For. Res. 56(1): 105-122, 2013.

[13]. J.Q. Chambers et al. Tree damage, allometric relationships, and above-ground net primary production in central Amazon forest, Forest Ecology Management, Vol. 152, pp. 73-84, 2001.

[14]. J. Chave, B. Riera, and M.A. Dubois, Estimation of biomass in a neotropical forest of French Guiana: spatial and temporal variability. Journal of Tropical Ecology 17:79-96, 2001.

[15]. J. Chave et al., Error propagation and scaling for tropical forest biomass estimates. Philosophical Transactions Royal Society B 359, 409-420, 2004.

[16]. J. Chave et al., Tree allometry and improved estimation of carbon stocks and balance in tropical forests, Oecologia 145: 87-99, 2005.

[17]. CIFOR, Forests and climate change mitigation. Center for International Forestry Research. Key research finding, pp.1-2, 2012.

[18]. N. A. Djomo et al., Allometric equations for biomass estimations in Cameroon and pan moist tropical equations including biomass data from Africa. Elsevier Sciencedirect. Forest Ecology and Management, Vol. 260, pp. 1873-1885, 2010.

[19]. E. Alvarez et al., Tree above-ground biomass allometries for carbon stocks estimation in the natural forests of Colombia, Elsevier, Science Direct, Forest Ecology and Management 267: 297-308, 2012.

[20]. R. Ekoungoulou, X. Liu, S.A. Ifo, J.J. Loumeto and F. Folega. Carbon stock estimation in secondary forest and gallery forest of Congo using allometric equations. International Journal of Scientific \& Technology Research, 3(3): 465-474, 2014.

[21]. W.R. Gorte, Carbon Sequestration in Forests, Congressional Research Service, Natural Resources Policy, Report for Congress, 7-5700 www.crs.gov RL31432, 2009.

[22]. FAO, State of the World's Forests, Food and Agriculture Organization of United Nations (UNFAO), Rome, Italy, pp.41-60, 2008.

[23]. FAO. Forest global resource assessment. Food and Agriculture Organization of United Nations (UNFAO). FAO forestry paper 163. Main report. Rome, Italy, pp. 213-378, 2010.

[24]. FAO, State of the World's Forests (Situation des forets du monde), Organisation des Nations Unies pour l'Alimentation et l'Agriculture, Rome, Italy, pp. 102$177,2011$.

[25]. F. Folega et al., Ecological and numerical analysis of plant communities of the most conserved protected area in North-Togo, International Journal of Biodiversity and Conservation, 2(10): 359-369, 2010

[26]. F. Folega, Wooded vegetation of protected areas in Northern Togo, Case of Barkoissi, Galangashi and OtiKeran: Ecological and Structure Analysis of Plant Communities, Forestry Studies in China, 13(1):23-35, 2011.

[27]. IPCC, Third Assessment Report of IPCC, Climate Change: The Scientific Basis. Contribution of Working Group 1 to the Third Assessment Report of the Intergovernmental Panel on Climate Change(IPCC), Cambridge, United Kingdom and New York, USA, Cambridge University Press, pp.608-881, 2001

[28]. IPCC, Renewable energy sources and climate change mitigation. Special report of the Intergovernmental Panel on Climate Change, Summary for policymakers and technical summary. WMO. UNEP, pp. 101-246, 2011.

[29]. A. Hall, Forests and climate change. The Social dimensions of REDD (Reducing Emissions from Deforestation and Forest Degradation) in Latin America, pp.97-213, 2012.

[30]. J. R.Holdaway et al., Propagating Uncertainty in Plotbased Estimates of Forest Carbon Stock and Carbon Stock Change, Uncertainty in Forest Carbon Estimates, Ecosystems. Pp. 2-14, 2014.

[31]. K. Lorenz, and R. Lal, 'Carbon sequestration in forest ecosystems", Springer, pp. 241-260, USA, 2009.

[32]. J. Makany, Végétation des Plateaux Teke. Travaux Universitaires. Université Marien Ngouabi. Brazzaville, Congo, pp.278-301, 1976.

[33]. K. Mokany, R.J. Raison, and A.S. Prokushkin, Critical analysis of root: shoot ratios in terrestrial biomes. Global Change Biology 12: 84-96, 2006

[34]. L. Moundzeo et al., Carbon sequestration in sugarcane plantation in Niari valley in Congo. Journal of Environmental Science and Technology 4 (4): 411-418, 2011.

[35]. J. Nguema and Pavageau, Adaptation et atténuation en Guinée équatoriale. Acteurs et processus politiques, Document de Travail 98, Center for International Forestry Research (CIFOR), pp. 23-62, Bogor, Indonesia, 2012.

[36]. J.S. Nkounkou, Flore du sanctuaire de Lesio-louna. Rapport de mission pédagogique. Projet Protection des Gorilles (PPG). Université Marien Ngouabi. Faculté des Sciences. Unpublished, pp. 3-20, 2003.

[37]. H. Ogawa et al., Comparative ecological studies on three main types of forest vegetation in Thailand II Plant biomass, Nat Life Southeast Asia 4:49-800, 1965

[38]. T.S. Pearson et al., Impact of Selective logging on the carbon stocks of tropical forests: Bolivia and the Republic of Congo as case studies, Submitted for publication, pp. 5-9, 2005.

[39]. T.S. Pearson et al., Use of aerial digital imagery to measure the impact of selective logging on carbon stocks of tropical forests in the Republic of Congo. Delivelable 9: to USAID, Cooperative Agreement No. EEM- A- 00-03-00006-00, pp. 5-21, 2005.

[40]. T.S. Pearson and S.Brown, Guide for measuring and monitoring carbon in forests and grasslands (Guide de mesure et de suivi du carbone dans les forêts et prairies herbeuses), Winrock International, pp.12-35, 2005.

[41]. A. J. Richard and W.W. Dean Applied Multivariate Statistical Analysis, Sixth Edition, Pearson Education Beijing Office, Tsinghua university press, China, pp. 563-755, 2007.

[42]. S.S Saatchi., Harris L.N., Brown S., Lefsky M., Mitchard E.T.A., Salas W., Zutta B.R, Buermann W., Simon L. Lewis S., Hagen S., Petrova S., White L., Silman M., and Morel A., Benchmark map of forest carbon stocks in tropical regions across three continents. Environmental Sciences. PNAS Early edition, pp.1-6, 2011. 
Tree Above-And Below-Ground Biomass Allometries For Carbon Stocks Estimation In Secondary...

[43]. UNFCCC. Synthesis and assessment report on the greenhouse gas inventories. United Nations Framework Convention on Climate Change (UNFCCC), pp.201-248, 2011.

[44]. A.Verissimo, P.Barreto, M.Mattos, R.Tarifa, C. Uhl Logging impacts and prospects for sustainable forest management in an old Amazonian frontier: The case of Paragominas. Forest Ecology and Management, 55: 169199, 1992.
[45]. R.T. Watson., I.R. Noble, B. Bolin, N.H. Ravindranath., D.J.Verardo, and D.J. Donken. Land Use, Land-Use Change and Forestry. Special Report of the Intergovernmental Panel on Climate Change. Cambridge University Press. USA, Cambridge, pp.220-375, 2000. 